Al-Mashrafiyah: Jurnal Ekonomi, Keuangan dan Perbankan Syariah ISSN (p): 2597-4904 ISSN (e) : 2620-5661

Volume 4 , Nomor 2 , Oktober (2020), h. 29-41

https://doi.org/10.24252/al-mashrafiyah.v4i2.15867

\title{
KELAYAKAN NASABAH DALAM PEMBERIAN PEMBIAYAAN PADA PT. BANK PEMBIAYAAN RAKYAT SYARIAH IMB KOTA MAKASSAR
}

\author{
Amiruddin K \\ Universitas Islam Negeri Alauddin Makassar \\ amir.uin@yahoo.com
}

Received: 12-9-2020; Revised: 29-2-2020; Accepted; 19-10-2020

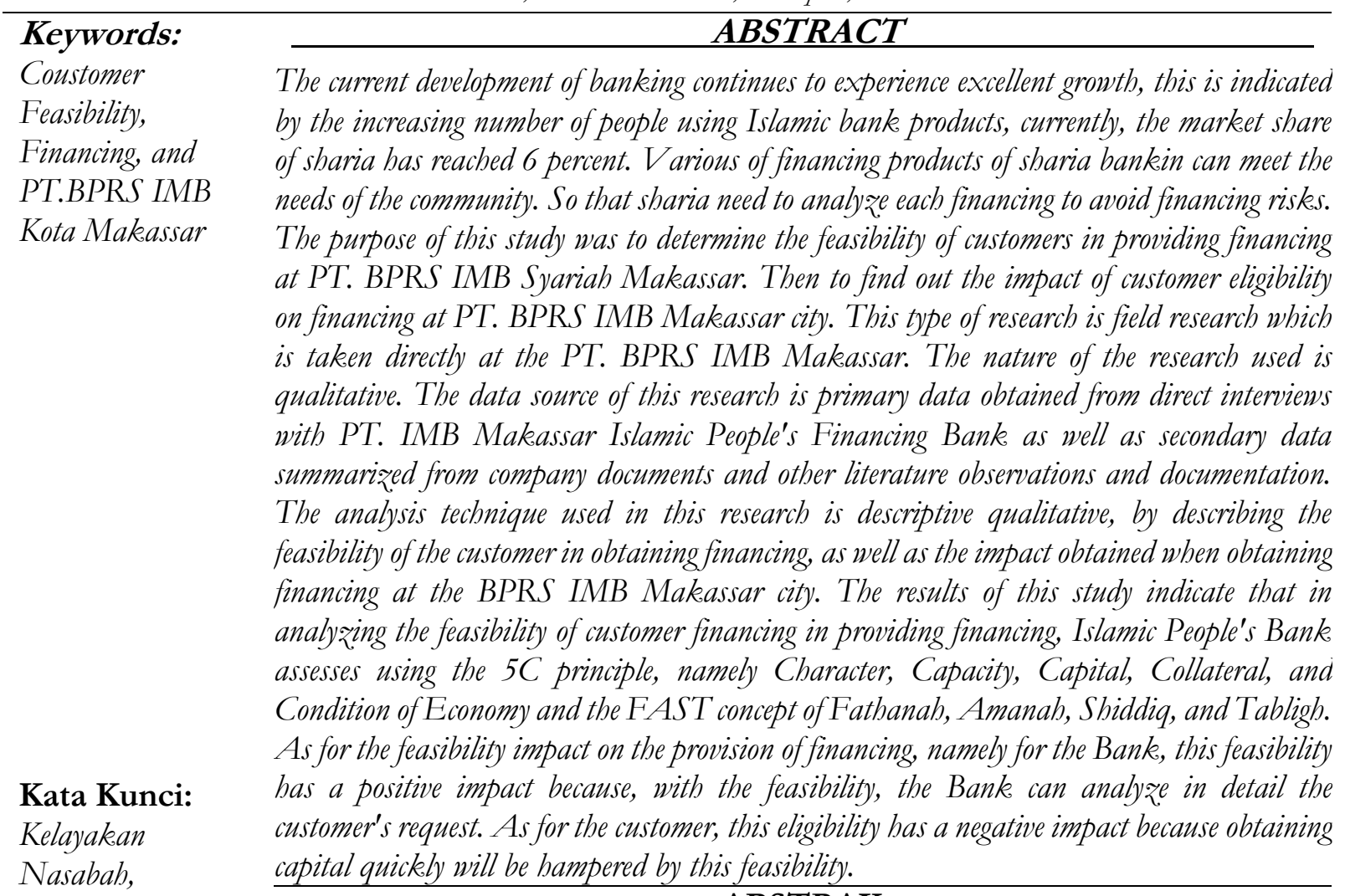

Pembiayaan, dan

ABSTRAK

PT. BPRS IMB

Kota Makassar

Perkembangan perbankan saat ini terus mengalami pertumbuhan yang sangat baik, hal ini ditandai dengan makin banyakeknya masyarakat yang menggunakan produk bank syariah, saat ini pangsa pasar bank syariah telah mencapai 6 persen. Produk-produk pembiayaan di bank syariah yang bervariasi dapat memenubi kebutuhan masyarakat. Sebingga bank syariah perlu melakukan analisis terhadap setiap pembiayaan untuk menghindari risio pembiayaan. Adapun tujuan penelitian ini untuk mengetabui kelayakan nasabah dalam pemberian pembiayaan pada PT. Bank Pembiayaan Rakyat Syariah IMB kota Makassar. Kemudian untuk mengetahui dampak kelayakan nasabab terhadap pemberian pembiayaan pada PT. Bank Pembiayaan Rakyat Syariah IMB kota Makassar. Jenis penelitian yang digunakan adalah penelitian lapangan yang diambil langsung di BPRS IMB kota Makassar. Sifat penelitian yang digunakan adalab kualitatif. Adapun sumber data penelitian ini adalah data primeryang diperoleh dari hasil wawancara secara langsung dengan pibak. PT. Bank Pembiayaan Rakyat Syariah IMB Makassar serta data sekunder yang dirangkum dari dokumen-dokumen perusahaan serta literatur lain observasi dan dokumentasi. Teknik analisis yang digunakan dalam penelitian ini adalab deskriptif kualitatif, dengan menguraikan kelayakan nasabah dalam memperoleh pembiayaan, serta 
dampak yang diperoleh ketika memperoleh pembiayaan di BPRS IMB kota Makassar. Hasil penelitian ini menunjukkan babwa dalam menganalisis kelayakan Pembiayaan nasabah dalam pemberian pembiayaan, Bank Rakyat Syariah melakukan penilaian dengan menggunakan prinsip 5C yaitu Character, Capacity, Capital, Collateral, and Condition of Economy dan konsep FAST yaitu Fathanah, Amanah, Shiddiq, dan Tabligh. Adapun dampak kelayakan terbadap pemberian pembiayaan yakni untuk pibak Bank, kelayakan ini berdampak positif karena dengan adanya kelayakan maka pibak Bank dapat menganalisis secara detail permohonan nasabah. Sedangkan untuk pibak nasabah, kelayakan ini berdampak negatif karena untuk mendapatkan modal secara cepat akan terbambat dengan adanya kelayakan ini.

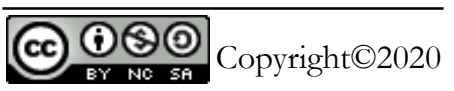

\section{PENDAHULUAN}

Masyarakat di Negara maju dan berkembang sangat membutuhkan Bank sebagai tempat untuk melakukan transaksi keuangannya. Mereka menganggap bank merupakan lembaga keuangan yang aman dalam melakukan berbagai macam aktivitas keuangan. Aktivitas keuangan yang sering dilakukan masyarakat di Negara maju dan Negara berkembang antara lain aktivitas penyimpanan dan penyaluran dana. Perbankan sebagai salah satu lembaga keuangan yang mempunyai peranan penting dalam kehidupan suatu Negara. Jasa layanan yang diberikan kepada masyarakat mendukung laju pertumbuhan ekonomi dan dapat memperlancar kegiatan perekonomian. Peran strategis Bank tersebut disebabkan oleh arti sederhana bank yang sebagai "lembaga keuangan yang kegiatan utamanya adalah menghimpun dana dari masyarakat dan menyalurkannya kembali dana tersebut ke masyarakat serta memberikan jasa lainnya (Kasmir, 2020).

Bank sebagai pihak perantara atau mediator penyaluran dan penghimpunan dana antara pihak yang kelebihan dana dengan pihak yang kekurangan dana diharapkan dapat memberikan kemanfaatan yang besar bagi masyarakat. Melalui bank, dana yang berpotensi investasi yang ada dimasyarakat dapat diberdayakan dan disalurkan dalam beberapa kegiatan produktif, sehingga harapan untuk mewujudkan perekonomian yang sehat dan terwujud.

Bank sebagai pihak perantara atau mediator penyaluran dan penghimpunan dana antara pihak yang kelebihan dana dengan pihak yang kekurangan dana diharapkan dapat memberikan kemanfaatan yang besar bagi masyarakat. Melalui bank, dana yang berpotensi investasi yang ada dimasyarakat dapat diberdayakan dan disalurkan dalam beberapa kegiatan produktif, sehingga harapan untuk mewujudkan perekonomian yang sehat dan terwujud.

Perkembangan perbankan syariah di Indonesia telah menjadi tolak ukur keberhasilan eksistensi ekonomi syariah. Bank syariah memiliki sistem operasional yang berbeda dengan bank konvensional. Bank syariah memberikan layanan bebas bunga kepada para nasabahnya. Dimana perbankan syariah adalah segala sesuatu yang menyangkut bank syariah dan unit usaha syariah, mencakup kelembagaan, kegiatan usaha, serta cara dan proses dalam melakukan kegiatan usahanya. Adapun salah satu produk bank syariah yang sangat membedakan dengan bank konvensional adalah pembiayaan kerja sama usaha. Dalam pembiayaan kerja sama usaha, bank syariah tidak membebani bunga kepada nasabah, akan tetapi ikut serta dalam investasi. Hasil investasi akan diterima dalam bentuk bagi hasil atas usaha yang dijalankan oleh calon nasabah. Dalam pembiayaan kerja sama usaha, dibedakan menjadi dua jenis pembiayaan yaitu pembiayaan Mudharabah dan pembiayaan Musyarakah (Ascarya, 2013).

Pembiayaan Mudharabah merupakan akad pembiayaan antara bank syariah sebagai shabibul maal dan nasabah sebagai mudharib untuk melaksanakan kegiatan usaha, dimana bank syariah memberikan modal sebanyak $100 \%$ dan nasabah menjalankan usahanya. Hasil usaha atas pembiayaan mudharabah akan dibagi antara bank syariah dan nasabah dengan nisbah bagi hasil yang telah disepakati pada saat akad. Dalam pembiayaan mudharabah, terdapat dua pihak yang melaksanakan perjanjian kerja sama yaitu Bank Syariah dan Nasabah (Ismail,2011). 
Pembiayaan Musyarakah merupakan akad kerja sama usaha antara dua pihak atau lebih dalam menjalankan usaha, dimana masing-masing pihak menyertakan modalnya sesuai dengan kesepakatan, dan bagi hasil atas usaha bersama diberikan sesuai dengan kontribusi dana atau sesuai kesepakatan bersama. Musyarakah disebut juga dengan Syirkah, merupakan aktivitas berserikat dalam melaksanakan usaha bersama antara pihak-pihak yang terkait. Dalam syirkah, dua orang atau lebih mitra menyumbang untuk memberikan modal guna menjalankan usaha atau melakukan investasi untuk suatu usaha.

Pembiayaan yang sering digunakan pada Bank Sul-SelBar Syariah yakni pembiayaan Murabahah. Murabahah merupakan istilah dalam fikih islam yang berarti suatu bentuk jual beli tertentu ketika penjual menyatakan biaya perolehan barang, meliputi harga barang dan biaya-biaya lain yang dikeluarkan untuk memperoleh barang tersebut dan tingkat keuntungan yang diinginkan.

Faktor yang menjadi sumber pendapatan utama bank syariah adalah asset produktif dalam bentuk pembiayaan. Semakin banyak dana yang bisa disalurkan dalam pembiayaan berarti semakin tinggi earning asset, artinya dana yang dihimpun dari masyarakat dapat disalurkan dalam bentuk pembiayaan produktif sehingga tidak banyak asset yang menganggur. Pembiayaan bermasalah adalah suatu penyaluran dana yang dilakukan oleh lembaga pembiayaan seperti bank syariah yang dalam pelaksanaan pembayaran pembiayaan oleh nasabah. Dari kegiatan pembiayaan ini, semakin banyak dana yang disalurkan maka potensi timbulnya risiko pun semakin besar. Hal ini karena pembiayaan merupakan salah satu aktivitas perbankan yang memiliki risiko disebabkan oleh adanya ketidak mampuan peminjam untuk melunasi kewajibannya kepada pihak bank. Besarnya risiko pembiayaan ditunjukkan dalam rasio Non Performing Finance (NPF). Tingginya NPF menunjukkan banyaknya jumlah peminjam yang tidak dapat mengembalikan pinjaman sesuai dengan perjanjian awal yang telah disepakati bersama antara bank dengan peminjam.

Pembiayaan dengan kolektibilitas kurang lancar, diragukan, dan macet termasuk dalam NPF. Semakin besar NPF menunjukkan semakin tinggi tingkat pembiayaan bermasalah, sehingga mengakibatkan turunnya pendapatan yang berpengaruh pada kinerja, tingkat kesehatan dan kelangsungan bank. Pembiayaan bermasalah atau macet memberikan dampak yang kurang baik bagi Negara, masyarakat, dan bank. Bahaya atas pembiayaan macet yakni tidak terbayarnya kembali pembiayaan yang diberikan, baik sebagian atau seluruhnya (Syafi'i,2001).

Semakin besar pembiayaan macet yang dihadapi oleh bank, maka menurun pula tingkat kesehatan bank mempengaruhi tingkat Likuiditas dan Solvabilitas, yang dapat mempengaruhi kepercayaan para penitip dana atau para nasabah. Demikian pula, semakin besar jumlah pembiayaan bermasalah, maka semakin besar jumlah dana cadangan yang harus disediakan oleh bank tetapi semakin besar pula tanggungan bank untuk mengadakan dana cadangan tersebut. Adapun dampak yang ditimbulkan oleh pembiayaan bermasalah tersebut menguatkan keharusan bank untuk berusaha mengupayakan penanggulangan ataupun pencegahan bahaya yang mungkin timbul akibat pembiayaan bermasalah tersebut.

Analisis pembiayaan merupakan suatu proses analisis yang dilakukan oleh bank syariah untuk menilai suatu permohonan pembiayaan yang telah diajukan oleh calon nasabah. Dengan melakukan analisis permohonan pembiayaan, bank syariah akan memperoleh keyakinan bahwa proyek yang akan dibiayai layak (feasible). Bank melakukan analisis pembiayaan dengan tujuan untuk mencegah secara dini kemungkinan terjadinya default oleh nasabah. Analisis pembiayaan merupakan salah satu faktor yang sangat penting bagi bank syariah dalam mengambil keputusan untuk menyetujui atau menolak permohonan pembiayaan, dengan analisis yang baik akan menghasilkan keputusan yang tepat. Analisis pembiayaan merupakan salah satu faktor yang dapat digunakan sebagai acuan bagi bank syariah untuk meyakini kelayakan atas permohonan pembiayaan nasabah.

Berkaitan dengan pembiayaan di bank syariah, dalam melakukan penilaian permohonan pembiayaan bank syariah bagian marketing harus memperhatikan beberapa prinsip dan analisis utama yang berkaitan dengan kondisi secara keseluruhan calon nasabah, sehingga bisa mengurangi tingkat pembiayaan bermasalah calon nasabah di dunia perbankan syariah. Adapun prinsip dasar yang perlu dilakukan sebelum memutuskan permohonan pembiayaan yang diajukan oleh calon nasabah antara lain dikenal dengan prinsip " $5 \mathrm{C}$ " dan analisis " $6 \mathrm{~A}$ ". penerapan prinsip dasar dalam pemberian pembiayaan serta analisis yang mendalam terhadap calon nasabah, perlu dilakukan oleh 
bank syariah agar bank tidak salah memilih dalam menyalurkan dananya sehingga dana yang disalurkan kepada nasabah dapat terbayar kembali sesuai dengan jangka waktu yang diperjanjikan. Maka tujuan utama analisis pembiayaan adalah menilai mutu permintaan pembiayaan baru yang diajukan oleh calon debitur ataupun permintaan pembiayaan terhadap pembiayaan yang sudah pernah diberikan yang diajukan oleh debitur yang lama. Sehingga dengan adanya analisis tersebut maka akan meminimalisir adanya pembiayaan yang bermasalah (Ismail,2011).

Sehingga terdapat pokok permasalahan yang terjadi pada Bank Pembiayaan Rakyat Syariah yakni adanya penyimpangan (Moral Hasard) terhadap calon nasabah, artinya permohonan pembiayaan yang diajukan oleh calon nasabah tidak secara detail di analisis oleh pihak bank di akibatkan adanya kerjasama antara pihak bank dengan pihak nasabah. Dari uraian tersebut peneliti merasa tertarik untuk melakukan penelitian lebih dalam terkait dengan kelayakan nasabah dalam pemberian pembiayaan pada PT. Bank Pembiayaan Rakyat Syariah IMB di kota Makassar. Kemudian terkait dengan dampak kelayakan terhadap pemberian pembiayaan pada PT. Bank Pembiayaan Rakyat Syariah IMB kota Makassar.

\section{LANDASAN TEORI}

Menurut Zainul Arifin (2005) bank adalah badan usaha yang menghimpun dana dari masyarakat dalam bentuk simpanan dan menyalurkannya kepada masyarakat dalam bentuk kredit, atau dalam bentuk lainnya dalam rangka menerapkan taraf hidup rakyat banyak. Selanjutnya Kasmir (2015) menjelaskan bahwa Bank syariah adalah bank yang berasaskan antara lain, pada asas kemitraan, keadilan, transparansi dan universal serta melakukan kegiatan usaha perbankan berdasarkan prinsip syariah.. Bank Syariah mempunyai beberapa bentuk penghimpunan dana, produk-produk pendanaan bank syariah ditujukan untuk mobilisasi dan investasi tabungan untuk pembangunan perekonomian dengan cara yang adil sehingga keuntungan yang adil dapat dijamin bagi semua pihak. Tujuan mobilisasi dana merupakan hal penting karena Islam secara tegas mengutuk penimbunan tabungan dan menuntut penggunaan sumber dana secara produktif dalam rangka mencapai tujuan sosial ekonomi Islam (Adi marwan,2008).

Menurut Ismail (2011), Bank syariah memiliki tiga fungsi utama yaitu sebagai berikut:

1. Menghimpun dana dari masyarakat yang kelebihan dana. Bank syariah menghimpun dana dari masyarakat dalam bentuk titipan dengan menggunakan akad Al- Wadiah dan dalam bentuk investasi dengan menggunakan akad Al- Mudharabah.

2. Menyalurkan dana kepada masyarakat yang membutuhkan. Masyarakat dapat memperoleh pembiayaan dari bank syariah asalkan dapat memenuhi semua ketentuan dan persyaratan yang berlaku. Menyalurkan dana merupakan aktivitas yang sangat penting bagi bank syariah, bank menyalurkan dana kepada masyarakat dengan menggunakan bermacam-macam akad.

3. Pelayanan jasa perbankan. Pelayanan jasa bank syariah diberikan dalam rangka memenuhi kebutuhan masyarakat dalam menjalankan aktivitasnya. Berbagai jenis produk pelayanan jasa yang dapat diberikan oleh bank syariah antara lain jasa pengiriman uang, pemindahbukuan, dll. Pelayanan yang dapat memuaskan nasabah ialah pelayanan jasa yang cepat dan akurat. Harapan nasabah dalam pelayanan jasa bank ialah kecepatan dan keakuratannya.

Fungsi dan kedudukan bank syariah tidak terlepas dari peranan bank syariah. Di antara peranan bank syariah, adalah memurnikan operasional perbankan syariah sehingga dapat lebih meningkatkan kepercayaan masyarakat dan meningkatkan kesadaran syariah umat Islam sehingga dapat memperluas segmen dan pangsa pasar perbankan syariah, serta menjalin kerja sama dengan para ulama karena bagaimanapun peran ulama, khususnya di Indonesia, sangat dominan bagi kehidupan umat Islam. Secara khusus Muhammad menejalaskan tentang peranan bank syariah secara nyata dapat terwujud dalam beberapa aspek sebagai berikut:

1. Menjadi perekat nasionalisme baru, artinya bank syariah dapat menjadi fasilator aktif bagi terbentuknya jaringan usaha ekonomi kerakyatan.

2. Memberdayakan ekonomi umat dan beroperasi secara transparan. Artinya, pengelolaan bank 
syariah harus didasarkan pada visi ekonomi kerakyatan, dan upaya ini terwujud jika ada mekanisme operasi yang transparan.

3. Mendorong penurunan spekulasi di pasar keuangan. Artinya bank syariah mendorong terjadinya transaksi produktif dari dana masyarakat.

4. Mendorong pemerataan pendapatan. Artinya bank syariah bukan hanya mengumpulkan dana pihak ketiga namun dapat mengumpulkan dana Zakat, Infak, dan Shadaqah (ZIS).

Kasmir (2012) Menjelaskan Beberapa prinsip dasar yang perlu dilakukan sebelum memutuskan permohonan pembiayaan yang diajukan oleh calon nasabah anatara lain sebagai berikut:

\section{Character}

Menggambarkan tentang sifat atau watak nasabah. Analisis ini untuk mengetahui sifat atau watak seorang nasabah pemohon kredit, apakah memiliki watak atau sifat yang bertanggung jawab terhadap kredit yang diambilnya. Dari watak atau sifat ini, akan terlihat kemauan nasabah untuk membayar dalam kondisi sesulit apapun. Namun, sebaliknya jika nasabah tidak memiliki sifat yang mau membayar, nasabah akan berusaha mengelak untuk membayar dengan berbagai alasan tentunya. Watak atau sifat ini akan dapat dilihat dari masa lalu nasabah melalui pengamatan, pengalaman, riwayat hidup, maupun hasil wawancara dengan nasabah. Cara yang perlu dilakukan oleh bank untuk mengetahui character calon nasabah antara lain (Ismail,2011):

a) BI Checking

Bank dapat melakukan penelitian dengan melakukan BI Cheking, yaitu melakukan penelitian terhadap calon nasabah dengan melihat data nasabah melalui computer yang online dengan bank Indonesia. BI Cheking dapat digunakan oleh bank untuk mengetahui dengan jelas oleh nasabahnya, baik kualitas pembiayaan calon nasabah bila telah menjadi debitur lain.

b) Informasi dari pihak lain

Dalam hal calon nasabah masih belum memilki pinjaman di bank lain, maka cara yang efektif ditempuh yaitu dengan meneliti calon nasabah melalui pihak-pihak lain yang mengenal dengan baik calon nasabah. Misalnya, mencari informasi tentang karakter calon nasabah melalui tetangga, teman kerja, atasan langsung, dan rekan usahanya. Karakter merupakan faktor yang sangat penting dalam evaluasi calon nasabah.

\section{Capacity}

Yaitu analisis yang digunakan untuk melihat kemampuan keuangan nasabah dalam memenuhi kewajibannya sesuai jangka waktu pembiayaan. Kemampuan ini dapat dilihat dari penghasilan pribadi untuk pembiayaan konsumtif dan usaha yang dibiayai untuk pembiayaan perdagangan atau produktif. Kemampuan ini penting untuk dinilai agar tidak mengalami kerugian. Untuk menilai kemampuan nasabah dapat dinilai dari dokumen yang dimiliki.

Prosedur pemberian pembiayaan merupakan tahap-tahap yang harus dilakukan sebelum sesuatu pembiayaan diputuskan untuk diberikan. Dengan tujuan untuk mempermudah bank dalam menilai kelayakan suatu permohonan pembiayaan. Prosedur pemberian pembiayaan dibedakan menjadi dua yaitu untuk pembiayaan perorangan dan pembiayaan oleh suatu badan hukum, dan jika dilihat dari segi tujuannya yaitu pembiayaan konsumtif dan pembiayaan produktif (Kasmir,2008).

Secara umum prosedur pemberian pembiayaan atau pembiayaan oleh badan hukum adalah sebagai berikut (Kasmir,2012):

1) Pengajuan berkas-berkas

Dalam hal ini pemohon mengajukan permohonan pembiayaan yang dituangkan dalam bentuk proposal, yang kemudian dilampiri dengan berkas-berkas lain yang dibutuhkan:

1.1 Proposal hendaknya menjelaskan secara rinci mengenai latar belakang, maksud dan tujuan, besarnya pembiayaan yang dibutuhkan, jangka waktu pembayaran dan jaminan yang digunakan.

1.2 Melampirkan dokumen-dokumen yang meliputi foto kopi:

a) Akte notaries 
b) T.D.P (Tanda Tangan Perusahaan)

c) N.P.W.P (Nomor Pokok Wajib Pajak)

d) Neraca dan laporan rugi laba 3 tahun terakhir.

e) Bukti diri dari pimpinan perusahaan

f) Sertifikat jaminan

1.3 Selanjutnya dilakukan penilaian dilakukan sementara adalah dari neraca dan laporan laba rugi (Kasmir,2009).

2) Penyelidikan berkas pinjaman

Untuk mengetahui apakah berkas yang diajukan sudah lengkap sesuai persyaratan dan sudah benar, termasuk menyelidiki keabsahan berkas.

3) Wawancara awal

Penyelidikan kepada calon debitur dengan langsung berhadapan dengan calon debitur. Tujuannya adalah untuk meyakinkan bank apakah berkas-berkas tersebut sesuai dan lengkap seperti dengan yang bank inginkan.

4) On the spot

Merupakan kegiatan pemeriksaaan kelapangan dengan meninjau berbagai obyek yang akan dijadikan usaha atau jaminan. Kemudian hasil on the spot dicocokan dengan hasil wawancara awal.

5) Wawancara kedua

Merupakan kegiatan perbaikan berkas, jika mungkin ada kekurangan-kekurangan pada saat setelah dilakukan on the spot dilapangan.

6) Keputusan pembiayaan

Menentukan apakah pemberian pembiayaan atau pembiayaan akan diberikan atau pun ditolak, jika diterima maka, diapersiapkan administrasinya. Jika permohonan pembiayaan ditolak maka dikirim surat penolakan sesuai dengan alasannya masing-masing.

7) Penandatangan akad pembiayaan perjanjian yang lainnya

Setelah permohonan tersebut diterima maka sebelum pembiayaan dicairkan terlebih dulu calon nasabah menandatangani akad pembiayaan, mengikat jaminan dengan hipotik dan surat perjanjian atau pertanyaan yang dianggap perlu.

8) Realisasi pembiayaan

Realisasi pembiayaan diberikan setelah penandatanganan akad pembiayaan dan suratsurat yang diperlukan dengan membuka rekening giro atau tabungan di bank yang bersangkutan. 9) Penyaluran penarikan dana

Pencairan atau pengambilan uang dari rekening sebagai realisasi dari pemberian pembiayaan dan dapat diambil sesuai ketentuan dan tujuan pembiayaan yaitu sekaligus dan secara bertahap.

\section{METODE PENELITIAN}

Penelitian ini mengambil metode penelitian kualitatif deskriptif. Peneliti mendeskripsikan tentang objek dengan mencatat apa yang ada dalam objek penelitian. Dengan ini dituntut keterlibatan peneliti secara aktif dalam pengumpulan data penelitian. Yang dimaksudkan mengetahui informasi terkait kelayakan (Burhan, 2012).

Pengumpulan data adalah prosedur yang sistematis dan standar untuk memperoleh data yang diperlukan (Moh Natsir, 2003). Pengumpulan data yang dilakukan untuk memperoleh informasi yang dibutuhkan dalam rangka mencapai tujuan penelitian.

Untuk mengumpulkan data mengenai objek penelitian maka digunakan metode pengumpulan data sebagai berikut:

1. Tekhnik Observasi

Tekhnik observasi merupakan metode pengumpulan data dengan melakukan pengamatan terhadap objek yang diteliti. Tekhnik observasi yang dilakukan adalah observasi langsung terhadap pihak PT. Bank Sul-SelBar Syariah Makassar sebagaimana yang dijelaskan oleh Winarno Surakhmad, bahwa: "Tekhnik pengumpulan data dimana peneliti mengadakan pengamatan secara 
langsung (tanpa alat) terhadap gejala-gejala subjek yang diselidiki, baik pengamatan itu dilakukan di dalam situasi sebenarnya maupun dilakukan di dalam situasi buatan yang khusus diadakan (Lexy, 2009).

\section{Wawancara}

Wawancara adalah percakapan dengan maksud tertentu. Percakapan itu dilakukan oleh dua pihak yaitu pewawancara yang mengajukan pertanyaan dan terwancara yang memberikan jawaban atas pertanyaan tersebut (Lexy, 2009). Menurut Bagong Suyanto Wawancara biasanya dimaksudkan untuk memperoleh keterangan, pendirian, pendapat secara lisan dari seseorang (yang lazim disebut responden) dengan berbicara langsung (face to face) dengan orang tersebut . Dalam hal ini peneliti melakukan wawancara dengan beberapa pegawai dalam Bank Sul-SelBar Syariah untuk memperoleh data yang dibutuhkan dan dianggap akurat.

\section{Dokumentasi}

Dokumentasi yaitu data yang dimaksudkan untuk melengkapi hasil data yang diperoleh melalui wawancara dan observasi. Metode ini digunakan untuk menguatkan data-data yang telah didapatkan.

Menurut Lexy (2002, Data yang diperoleh dari informasi perlu diteliti kebenarannya dengan cara melakukan perbandingan data yang diperoleh dari informasi yang lain. Keabsahan data dalam penelitian ini diperiksa dengan tekhnik trianggulasi, yaitu tekhnik penilaian keabsahan data yang memanfaatkan sesuatu diluar data itu untuk keperluan pengecekan sebagai pembanding data-data tersebut.

Dalam tekhnik trianggulasi, terdapat alasan tertentu untuk penilaian data tersebut, yaitu sebagai berikut:

1. Penelitian ini dilakukan oleh peneliti sendiri. Maka pengumpulan data yang dilakukan pemeriksaan ulang.

2. Tekhnik pengumpulan data yang digunakan untuk data kelayakan pemberian pembiayaan kepada nasabah ialah melalui sumber data tertulis.

Melalui tekhnik diatas, peneliti melakukan pengecekan ulang atas hasil pengumpulan data untuk mendapatkan data yang akurat.

Analisis data yang digunakan dalam penelitian ini adalah deskriptif kualitatif. Deskriptif kualitatif bertujuan untuk mendeskripsikan suatu peristiwa atau kejadian yang saat ini berlaku. Dengan kata lain penelitian ini tidak mencari tahu menjelaskan hubungan,tetapi hanya berbentuk narasi yang bertujuan untuk mengumpulkan informasi actual secara rinci yang menjelaskan tentang analisis kelayakan pemberian pembiayaan pada PT. BPRS IMB Makassar. Adapun aktifitas dalam analisis data yaitu sebagai berikut:

1. Reduksi data

Mereduksi data berarti merangkum, memilih hal-hal yang pokok, memfokuskan pada halhal yang penting, dicari tema dan pola serta membuang yang tidak perlu. Dengan demikian data yang telah direduksi akan memberikan gambaran yang lebih jelas dan mempermudah peneliti untuk melakukan pengumpulan data selanjutnya dan mencarinya bila diperlukan.

2. Penyajian data

Hal yang paling sering digunakan untuk menyajikan data dalam penelitian kualitatif adalah dengan teks yang bersifat naratif. Dengan penyajian data, maka akan memudahkan untuk memahami apa yang telah terjadi, merencanakan kerja selanjutnya berdasarkan apa yang telah dipahami tersebut.

\section{Verification}

Kesimpulan dalam penelitian kualitatif mungkin dapat menjawab rumusan masalah yang dirumuskan sejak awal, tetapi mungkin juga tidak, karena seperti yang telah dikemukakan bahwa masalah dan rumusan masalah dalam penelitian kualitatif masih bersifat sementara dan akan berkembang setelah peneiliti berada di lapangan.

\section{HASIL DAN PEMBAHASAN}




\section{Analisis PT Bank Pembiayaan Syariah Investama Mega Bakti Makassar Terhadap Kelayakan Nasabah dalam Pemberian Pembiayaan}

Pembiayaan merupakan salah satu produk yang dimiliki oleh suatu perbankan dalam menjalankan kegiatannya. Setiap perbankan memiliki standarnya masing-masing dalam menentukan kelayakan nasabah untuk diberi pembiayaan. Dengan demikian bank harus menentukan kadar risiko yang akan di pikulnya dalam setiap kasus dan berapa jumlah pembiayaan yang dapat disetujui dengan mempertimbangkan risiko. Risiko pembiayaan mempunyai dimensi kualitatif dan kuantitatif. Tetapi dimensi kualitatif itu pada umumnya lebih sulit untuk dinilai.

Yulianus Sumule, yang berperan sebagai analisis Pembiayaan pada PT. Bank Pembiayaan Rakyat Syariah Investama Mega Bakti (IMB) Makassar, mengatakan bahwa:

"Dalam menganalisis seorang nasabah/anggota yang pantas dan sesuai untuk menerima sebuah pembiayaan pada PT Bank Pembiayaan Rakyat Syariah Investama Mega Bakti Makassar, maka kami melakukan sebuah analisis dengan menggunakan prinsip pembiayaan yaitu 5C yaitu Charakter, Capacity, Capital, Collateral, Condition of ekonomic" (Yuliana Sumule,2017).

Yang dimaksud lima prinsip pembiayaan tersebut di atas dapat dijelaskan sebagai berukut :

1. Character

Untuk memperoleh gambaran tentang karakter nasabah dapat ditempuh upaya-upaya sebagai berikut:

a) Meneliti riwayat hidup dari calon mitra,

b) Meneliti reputasi di tempat uasaha calon mitra,

c) Meminta informasi dari bank ke bank yang pernah memberikan fasilitas pembiayaan,

d) Mencari informasi kehidupan calon nasabah dari lingkungan tempat tinggal.

2. Capacity

Untuk melihat kemampuan nasabah dalam membayar kewajibannya yang dihubungkan dengan kemampuannya mengelola bisnis serta kemampuannya mencari laba. Semakin banyak pendapatannya maka semakin besar kemampuannya dalam mengembalikan pinjamannya. Kita bisa menilai kapasity dari calon nasabah dengan cara:

a) Menilai kekayaan nasabah, dengan cara melihat seberapa besar asset yang dimiliki nasabah,

b) Melihat perkembangan usaha yang dilakukan oleh nasabah,

c) Melihat laporan keuangan dari usaha yang dilakukan oleh nasabah.

3. Capital

Modal yang dimaksud di sini adalah ketersediaan modal awal nasabah sebelum mengajukan pembiayaan. Poin capital ini tidak terlalu dipertimbangkan BPRS IMB Makassar dibandingkan dengan karakter, kapasitas dan agunan/jaminan. Akan tetapi poin ini masih dinilai juga demi keamanan dan kehati-hatian Bank BPRS IMB Makassar dalam menyalurkan pembiayaan.

4. Collateral

Menilai dan menganalisis agunan yang diajukan oleh calon nasabah ke Bank BPRS IMB Makassar. Nilai dari jaminan diharuskan jumlahnya tinggi dibandingkan dengan pinjamannya. Pinjaman diharuskan sebesar $75 \%$ dari nilai jaminan yang diagunkan. Menilai juga keabsahan atau keaslian dari jaminan, yang akan bisa dipergunakan secepat mungkin apabila terjadi suatu masalah.

5. Condition of Economy

Melihat kondisi lingkungan saat pemberian pembiayaan baik kondisi ekonomi yang terjadi maupun politik. Sehingga dibutuhkan kondisi stabil dalam pengukuran dana pembiayaan. Dan apabila dalam kondisi yang tidak stabil pembiayaan tetap diberikan maka perlu dilihat prospek usaha tersebut di masa yang akan datang.

Prinsip 5C ini merupakan prinsip dasar yang dipakai oleh Bank Pembiayaan Rakyat Syariah Investama Mega Bakti. Selain prinsip 5C ini yang digunakan oleh pihak bank, adapun 
prinsip lain yaitu prinsip FAST, yakni Fathanah, Amanah, Shiddiq, Tabligh (Fatmawati, 2017).

1. Fathanah, artinya cakap dan cerdas dalam menganalisis permohonan nasabah. Dalam hal ini meliputi dua unsure yakni:

a) Fathanah dalam administrasi atau manajemen dagang, artinya hal-hal yang berkenaan dengan aktivitas harus dicatat atau dibukukan secara rapi.

b) Fathanah dalam hal menangkap selera pembeli yang berkaitan dengan barang maupun harta.

2. Amanah, artinya tidak mengurangi apa-apa yang tidak boleh dikurangi dan sebaliknya tidak boleh ditambah. Dalam hal ini termasuk juga menambah harga jual yang telah ditentukan atas pengetahuan pemilik barang. Sifat amanah yang ada pada nasabah akan memberikan dampak positif bagi diri pelaku usaha yang dijalanimya. Sehingga usahanya akan semakin berkembang dan bank yang akan memberikan pembiayaan merasa yakin untuk memberikan pembiayaan.

3. Shiddiq, artinya benar dalam perkataan dan benar pula dalam perbuatan, pebisnis dilarang melakukan hal yang tidak baik. Apabila shiddiq dilakukan oleh pelaku bisnis maka praktek bisnis jahiliyah tidak terjadi perbuatan penipuan.

4. Tabligh, artinya komunikatif dan argumentatif. Yaitu orang yang memiliki sifat tabligh akan menyampaikan sesuatu dengan benar (berbobot) dan dengan tutur kata yang tepat.

Setalah pihak bank menganalisis permohonan nasabah dengan menggunakan konsep 5C dan konsep FAST, pihak bank tidak langsung pembiayaannya diterima, melainkan pihak analisis menyerahkan ke bagian DPS untuk menganalisis ulang, apakah nasabah layak atau tidak diberikan pembiayaan (Haris, 2017).

Begitu pula yang dikatakan oleh ibu Yani selaku analisis pembiayaan, mengatakan bahwa pembiayaan yang dominan diajukan oleh calon nasabah yakni pembiayaan KPR dengan akad Murabahah (Agunawan,2017). Adapun skema pembiayaan dengan akad Murabahah yaitu:

1. Negoisasi dan persyaratan

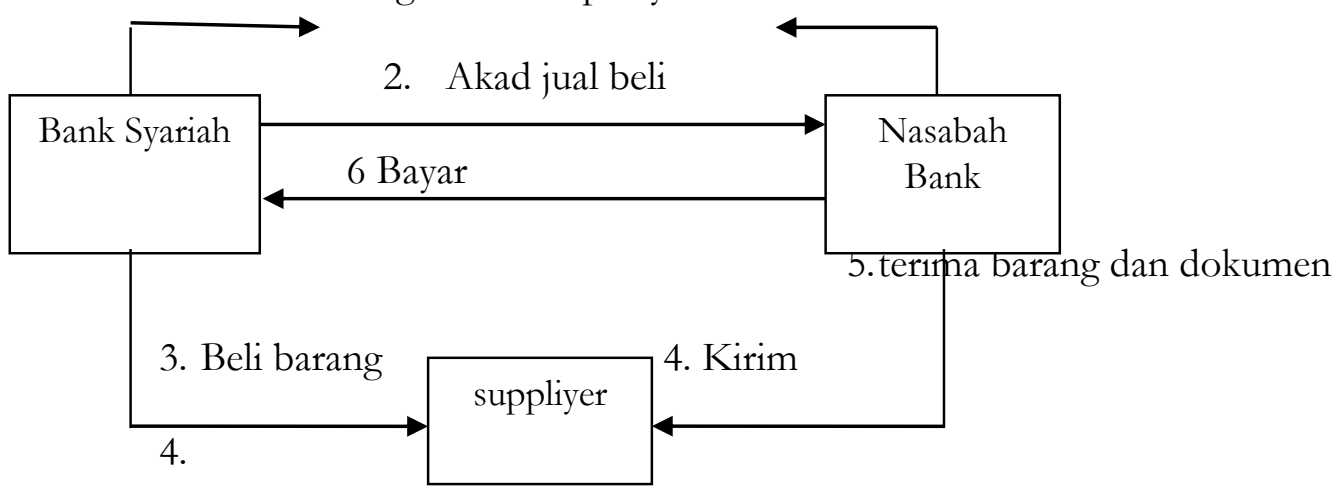

\section{Sumber: PT. Bank Pembiayaan Rakyat Syariah Investama Makassar}

Kredit Kepemilikan Rumah merupakan pembiayaan murabahah yang bersifat konsumtif. Dimana bank menyediakan pinjaman dana untuk membeli rumah, tanah kavling atau untuk merenovasi rumah yang diperlukan calon penerima kredit, untuk dibayar kembali saat jatuh tempo dengan cara cicilan. Pada saat akad, pembiayaan KPR diakui pada saat pencairannya sebesar pokok pembiayaan yang diberikan dan keuntungan yang disepakati. Keuntungan ini disebut margin yang merupakan pendapatan bank, dimana besarnya margin ditetapkan berdasarkan kesepakatan antara nasabah dan Bank BPRS IMB Makassar. Adapun marginnya yaitu 1-5 tahun sebesar 8,5\%, 6-10 tahun sebesar 9,5\% dan 11-15 tahun sebesar 10,5\%.

Selain itu, pihak bank juga menerapkan suatu batasan kepada nasabah sebelum nasabah diberikan pembiayaan yakni untuk modal usaha, dimana pihak bank harus melihat secara detail seberapa besar jaminan yang diajukan oleh nasabah. Seperti yang dijelaskan bahwa di dalam menjalankan suatu usaha apapun tentu mengandung suatu tingkat kerugian. Risiko ini dapat saja terjadi akibat suatu musibah yang tidak dapat dielakkan seperti terkena bencana alam, tetapi risiko 
yang paling fatal adalah akibat nasabah yang mampu, tetapi tidak mau membayar kewajibannya. Adanya risiko kerugian di mana nasabah tidak sanggup lagi membayar semua keajibannya baik untuk sementara waktu atau selamanya harus segera diantisipasi oleh pihak bank. Ketidakmampuan nasabah dalam melunasi kreditnya, dapat ditutupi dengan suatu jaminan kredit. Fungsi jaminan kredit adalah untuk melindungi bank dari kerugian. Dengan adanya jaminan kredit dimana nilai jaminan biasanya melebihi nilai kredit, maka bank akan aman. Bank dapat mempergunakan atau menjual jaminan kredit untuk menutupi kredit apabila kredit yang diberikan macet. Maka dari itu jaminan disini sangat berpengaruh terhadap pemberian pembiayaan kepada nasabah. Yang paling penting dalam jaminan kredit adalah mengikat nasabah untuk segera melunasi utang-utangnya.

Menurut Muh. Rifki Erdiansyah, jangka waktu pengembalian pinjaman sudah ditetapkan oleh pihak bank, akan tetapi pihak bank memberikan wewenang kepada pihak nasabah untuk menentukan jangka waktunya sendiri yang jelas tidak keluar dari jangka waktu yang ditetapkan oleh pihak bank. Muh. Rifki mengatakan bahwa kita disini memberikan kelonggaran kepada nasabah, agar nasabah bisa mengembalikan pinjaman yang dia ambil sesuai jangka waktu yang disepakati. Adapun jangka waktu yang ditetapkan oleh pihak bank, dimana untuk modal kerja jangka waktunya minimal 2 tahun, maksimal 5 tahun. Sedangkan untuk Investasi minimal 3 tahun, maksimal 5 tahun. Pada bank Sul-SelBar Syariah ini, jangka waktu yang sering disepakati oleh pihak nasabah dengan pihak bank pada pembiayaan modal kerja yaitu jangka waktu 2 tahun atau 3 tahun (Kamaluddin,2017).

Akan tetapi sepandai-pandainya analisis kredit dalam menganalisis setiap permohonan kredit, kemungkinan kredit tersebut mengalami kemacetan. Hal ini disebabkan oleh dua unsur sebagai berikut:

1. Dari pihak perbankan; artinya dalam melakukan analisisnya, pihak analisis kurang teliti, sehingga apa yang seharusnya terjadi tidak dapat diperkirakan sebelumnya. Hal ini dapat pula terjadi akibat kerja sama dari pihak analisis kredit dengan pihak debitur sehingga dengan melakukan analisisnya dilakukan secara subjektif.

2. Dari pihak nasabah; kemacetan kredit dapat dilakukan akibat dua hal yaitu: adanya unsur kesengajaan, artinya nasabah dengan sengaja bermaksud tidak membayar kewajibannya sehingga kredit yang diberikan macet. Adanya unsur tidak sengaja, artinya debitur mau membayar, tetapi tidak mampu. Sebagai contoh kredit yang dibiayai mengalami musibah seperti kebakaran, kena hama, kebanjiran, sehingga kemampuan untuk membayar kredit tidak ada.

Dalam kasus kredit macet ini pihak bank perlu melakukan penyelamatan, sehingga tidak akan menimbulkan kerugian. Penyelamatan yang dilakukan bisa dengan memberikan keringanan berupa jangka waktu pengembalian terutama bagi kredit yang mengalami musibah (Arifin, 2017).

Menurut Arifin Abdullah, penanganan pembiayaan yang dilakukan oleh pihak bank apabila terjadi pembiayaan bermasalah yakni:

1. Menjaga hubungan baik dengan nasabah, artinya ini bisa dilakukan jika nasabah/anggota masih memiliki prospek dan peluang yang baik bagi Bank BPRS IMB Makassar. Dengan demikian Bank Pembiayaan Rakyat Syariah Investama Mega Bakti, harus memiliki planning yang terarah. Dapat dilakukan dengan cara:

a) Restrukturisasi pembiayaan adalah upaya Bank Pembiayaan Rakyat Syariah Makassar melakukan perbaikan terhadap nasabah yang berpotensi atau mengalami kesulitan.

b) Pengembalian pokok, artinya dilakukan dengan cara pengalihan akad dari murabahah ke akad qardulhasan, ini bisa memperkecil angsuran dan meminimalkan terjadinya resiko.

c) Peringatan I,II,III, artinya peringatan diberikan secara bertahap mulai dari peringatan I, apabila peringatan I diabaikan maka peringatan II diberikan pula dan seterusnya sampai peringatan ke III. Baru pihak Bank Pembiayaan Rakyat Syariah IMB Makassar melakukan tindakan selanjutnya. Jangka antara surat peringatan I dengan surat peringatan lainnya adalah selama 3 bulan.

2. Penyitaan sampai penjualan barang agunan, artinya saat penyelesaian diatas sudah tidak bisa menyelesaikannya maka jalan terakhirnya adalah menjual/ melelang barang jaminan di 
lembaga keuangan. Dan besarnya harga jual kemudian di konversikan kepada pihak bank.

3. Evaluasi, yaitu untuk melakukan pengawasan dan mengontrol penanganan pembiayaan yang dilakukan.

4. Hapus Buku, artinya apabila nasabah/anggota yang melakukan pembiayaan tidak diketahui informasi dan kabarnya, maka pihak BPRS IMB Makassar berhak menghapus pembiayaan yang telah dilakukan.

\section{Dampak Kelayakan Terhadap Pemberian Pembiayaan Kepada Nasabah}

Dampak kelayakan sangatlah berpengaruh terhadap pemberian pembiayaan kepada nasabah, dimana kelayakan ini menjadi tolak ukur oleh pihak bank untuk memberikan kepastian layak atau tidaknya permohonan pembiayaan yang diajukan oleh pihak nasabah kepada pihak bank.

Menurut Sudri M. Aldiy, Komisaris PT. Bank Pembayaan Rakyat Syariah Investama Mega Bakti Makassar, adapun dampak kelayakan terhadap pemberian pembiayaan yakni kelayakan ini berdampak positif bagi pihak bank sebab dengan adanya kelayakan ini pihak bank dapat menilai setiap permohonan nasabah, apakah dia layak diberikan pembiayaan atau tidak. Maka dari itu sebelum pembiayaan diberikan maka bank harus merasa yakin bahwa pembiayaan yang akan diberikan benar-benar akan kembali. Keyakinan tersebut diperoleh dari hasil penilaian untuk mengetahui layak atau tidaknya diberikan pembiayaan. Penilaian ini dapat dilakukan dengan berbagai cara untuk mendapatkan keyakinan tentang nasabahnya, seperti melalui prosedur penilaian yang benar. Dalam melakukan penilaian kriteria-kriteria serta aspek penilaiannya tetap sama (Sudri, 2017).

Biasanya kriteria penilaian yang harus dilakukan oleh bank, untuk mendapatkan nasabah yang benar-benar menguntungkan dilakukan dengan analisis $5 \mathrm{C}$ dan $7 \mathrm{P}$. kredit dengan penilaian 5C berisi penilaian tentang Character, Capacity, Capital, Condition, dan Collateral. Sedangkan untuk 7P kredit adalah Personality, Party, Purpose, Prospect, Payment, Profitability, dan Protection.

Menurut nasabah atas nama bapak Ridwan mengatakan bahwa Kelayakan ini memberikan dampak negatif pada pihak nasabah karena dengan adanya kelayakan ini maka untuk mendapatkan penambahan modal akan membutuhkan waktu yang cukup lama, disebabkan karena pihak bank akan menilai secara detail apakah permohonan yang diajukan ini layak diberikan pembiayaan atau tidak (Muh Ridwan,2017).

Berbeda dengan apa yang dikatakan oleh Bapak Hardiawan, dia mengatakan bahwa :

Saya setuju dengan adanya kelayakan ini karena permohonan yang kita ajukan benar-benar dianalisis oleh pihak bank sehingga mengurangi jumlah nasabah yang melakukan pembiayaan macet (Hardiawan, 2017).

Apa yang dikemukakan Muh. Hardiwan tersebut di atas menunjukkan bahwa intrumen kelayakan nasabah adalah merupakan alat untuk menghindari terjadinya kemacetan dari kredit pembiayaan terhadap nasabah, sehingga pihak perbankan syariah tidak mengalami kerugian.

\section{PENUTUP}

Dari pembahasan yang telah dikemukakan sebelumnya, maka penulis dapat menarik suatu kesimpulan yakni:

1. Dalam menganalisis kelayakan nasabah untuk pemberian pembiayaan, PT. Bank Pembiayaan Rakyat Syariah IMB Makassar melakukan penilaian dengan menggunakan prinsip 5C, yaitu: Character, Capacity, Capital, Coleteral, Condition of Economy dan konsep FAST, yaitu Fathanah, Amanah, Shiddiq, Tabligh. Dengan tercapainya penilaian ini maka pihak bank dapat memutuskan layak atau tidaknya nasabah diberikan pembiayaan karena memberikan pembiayaan kepada nasabah tidaklah semudah itu melainkan kita harus waspada atas risiko yang akan terjadi pada pihak bank itu sendiri.

2. Adapun dampak kelayakan terhadap pemberian pembiayaan yakni untuk pihak bank sendiri akan berdampak positif sedangkan untuk pihak nasabah akan berdampak negatif. 
a) Untuk pihak bank sendiri, kelayakan ini akan berdampak positif dalam pemberian pembiayaan karena dengan adanya kelayakan maka pihak bank dapat menganalisis secara detail permohonan nasabah, apakah dia layak atau tidak diberikan suatu pembiayaan. Dengan adanya kelayakan ini maka peluang untuk terjadinya pembiayaan macet akan kecil.

b) Sedangkan untuk pihak nasabah, kelayakan ini akan berdampak negatif karena untuk mendapatkan modal secara cepat akan terhalang dengan adanya kelayakan ini. Karena untuk mendapatkan pembiayaan maka harus melalui analisis yang diterapkan oleh pihak bank, setelah analisis itu dapat tercapai maka pihak layak untuk diberikan pembiayaan. Oleh karena itu pihak nasabah untuk mendapatkan pembiayaan harus membutuhkan waktu yang relatif lama.

Adapun saran yang dapat penulis ungkapkan yakni sebagai berikut:

1. PT. Bank Pembiayaan Rakyat Syariah IMB hendaknya selalu menjaga prinsip kehatihatian dalam penyaluran pembiayaan pada semua pembiayaan yang diberikan.

2. Lebih memprioritaskan pembiayaan pada sector usaha kecil dan menengah dan pembiayaan produktif dari pada konsumtif.

3. Untuk kelancaran pembiayaan, maka pihak bank Sul-SelBar Syariah harus selalu melakukan pengawasan dan pembinaan terhadap perkembangan usaha nasabah.

\section{DAFTAR PUSTAKA}

Abdullah Thamrin. 2014. Bank dan Lembaga Kenangan. Jakarta: Rajawali Pers.

Ascarya. 2013. Akad dan Produk Bank Syariah. Jakarta: PT. Raja Grapindo Persada.

Arikunto Suharsimi. 1993. Prosedur Penelitian Ilmiah: Suatu Pendekatan Praktek. Jakarta: PT. Rineka Cipta.

Ali Zinuddin. 2008. Hukum Perbankan Syariah, Jakarta: Sinar Grafika.

Budiyati. 2008. Faktor-faktor yang Mempengarubi Pemberian Pembiayaan pada Baitul Maal wa Tamwil di Kabupaten Demak. Jurnal. Fakultas Ekonomi, Universitas Negeri Yogyakarta.

Bungain Burhan. 2012. Peneltian Kualitatif cetakan II. Jakarta: Kencana.

Darmawi Herman. 2014. Manajemen Perbankan. Jakarta: Bumi Akasara.

Fitriana Rarasati. 2007. Analisis Prosedur Pemberian Pembiayaan Mudharabah pada Bank Syariah Mandiri. Jurnal, Fakultas Ekonomi, Universitas Riau.

Husein Umar. 2005. Evaluasi Kinerja Perusahaan. Jakarta: PT. Gramedia Pustaka Utama.

Ismail. 2011. Perbankan Syariah. Jakarta: Pernada Media Group.

Ismail. 2010. Manajemen Perbankan dari Teori Menuju Aplikasi. Jakarta: Kencana Prenada Media Group.

Kasmir. 2009. Dasar-Dasar Perbankan. Jakarta.

Kasmir.2010. Manajemen Perbankan. Jakarta: Rajawali Press.

Kasmir. 2012. Analisis Laporan Kenangan. Jakarta: Rajawali Pers.

Kasmir. 2014. Bank Dan Lembaga Kenangan. Jakarta: Rajawali Pers.

Kasmir. 2015. Bank Dan Lembaga Keuangan Lainnya. Jakarta: Rajawali Pers.

Moeloeng Lexy. 2008. Metode Penelitian Ilmiah. Bandung: PT. Remaja Resdakarya.

Moeloeng Lexy J. 2008. Metodologi Penelitian Kualitatif. Bandung: Remaja Rosda Karya.

Muhamad. 2014. Manajemen Dana Bank Syariah. Jakarta: Rajawali Pers.

Natsir Moh. 2003. Metode Penelitian.Jakarta: Ghalia Indonesia. 
Subagyo Ahmad. 2008. Study Kelayakan. Jakarta: PT. Elex Media Komputindo.

Surakhmad Winarno. 1998. Pengantar Penelitian Ilmiah, Dasar Metode Tekhnik. Bandung.

Soemitra Andri. 2009. Bank dan Lembaga Kenangan Syariah.Jakarta: Prenada Media Group.

Syafi'I Muhammad. 2001. Bank Syariah dari Teori ke Praktek. Jakarta: Gema Insani Press, 2001.

Yusuf Muri A. 2011. Metode Penelitian. Jakarta: Prenada Media Group. 